\title{
4
}

\section{UNTHINKING CIVILISATION: AN IMBRICATED HISTORY OF THE OKHOTSK REGION}

Spring comes late to the Okhotsk Sea. In March, and into April in many places, ice grinds in wide sheets across the surface of the waters. Along the sea's western shores, and on the island of Sakhalin which extends parallel with these shores, winds still whip gusts of snow through the larch forests, where the first green is barely starting to appear on the tips of branches. In May, the temperature may still fall below freezing in Sakhalin and on the northern Kurile Islands to the east. But by June the short warm summer is beginning to spread from the southern shores of the sea as far north as the Kamchatka Peninsula. As the subsoil thaws to marsh, plants grow with startling speed - giant golden Amur lilies, umbrella plants whose stems will soon be as tall as a human being. Wild roses cover the sand dunes.

With the unfurling of plants comes a profusion of other life. Migrating birds fly back to the region across the Soya and Kunashir Straits. Bears, mink and squirrels emerge from hibernation, and mosquitoes and other insects that haunt the summer forests rise in clouds from the mossy earth. Until the early twentieth century, in April to May and again in June, two species of salmon used to swarm back in millions to their spawning grounds, and the rivers of the region would fill so full of fish that it was possible to scoop them out by hand. In September the forests turn golden, and cranberries appear in abundance between the trees. But already the snow is beginning to creep down from the higher slopes of the mountains, and by November it will cover the region again as the days grow short and the night-time temperatures fall below minus 30 degrees Celsius. 
This environment, with its bitter cold and extreme seasonal variations, sustains only a sparse population of people able to adjust to its rigours. But, just as it contains great natural diversity, so too it has contained great human diversity. It has been, and still is, home to many small societies and language groups. The names by which these groups defined themselves, and the ways in which they drew their own boundaries, have changed over time, but today we know them as the Ainu, who inhabit its southern shores, and at times in the past extended their range as far as the southern tip of Kamchatka and the lower reaches of the Amur River; the Itelmen of the Kamchatka Peninsula, and the Chukchee of the northern Okhotsk; the Nivkh, whose territory extends from the region around the mouth of the Amur across the north of the island of Sakhalin; the Uilta who herded reindeer in the forests of central and northern Sakhalin; the Evenk and Saha herders who moved into the region from the west in the nineteenth and early twentieth centuries; and many others. Among them, in the past three centuries, have lived migrants and colonisers from larger societies: the Manchu officials and Cossack adventurers who collected furs from the local communities in the seventeenth, eighteenth and early nineteenth centuries; Chinese and Korean farmers and hunters who moved into the Lower Amur region in growing numbers in the late nineteenth and early twentieth centuries; Japanese colonial settlers, hundreds of thousands of whom arrived in Hokkaido from the Meiji period onwards (and who also moved into southern Sakhalin and the southern Kurile Islands, only to be evicted again after Japan's defeat in war in 1945); the convicts and colonists who moved east from Russia and later from all parts of the Soviet Union; and the Korean workers brought (often forcibly) to Sakhalin by the Japanese colonial authorities during the 1930s and early 1940s.

Conventional history writing, which subdivides the region into national entities labelled 'Russia' and 'Japan', has often tended to obscure this diversity. Yet the human diversity of the region has been maintained, in constantly changing configurations, throughout modern history, and still survives in the twenty-first century, as the region is reshaped by new forces of inward and outward migration, global investment and cross-border flows of people, goods and ideas. The distinctive character of the Okhotsk Sea region - its harsh climate, low population density and human diversity makes it a particularly appropriate place to elaborate a particular approach to the past: an approach I refer to as 'imbricated history'. 
'Imbricated history' explores the historical connections between a variety of different social groups (both large and small, state and non-state) inhabiting an area whose environment encourages human interaction, but whose territory is transected by political or cultural frontier lines. In this way, it aims to illuminate some of the human connections and confluences that are obscured by conventional spatial frameworks of history writing: the framework of the nation-state and the framework of civilisation. All writers of history must draw horizons around their subject, and all horizons obscure parts of the world from view. Nation-states have had a decisive influence on the history of the world for the past several centuries, and will continue to have a decisive impact upon its future. It therefore remains important to write histories that operate within a national framework. It is also valuable to consider how the sharing of particular belief systems or material practices influence the past and present of societies. Provided that such categories are treated with care and reflection - not treated as eternal verities - there is surely a place for histories of (for example) the Japanese or Thai nations, the Islamic world, or the East Asian societies that shared a stock of political and social ideas originating in the Chinese empire.

But in taking a different - imbricated - standpoint for looking at past and present, I want to try to expose some issues that are obscured by the blind spots of national histories and histories of civilisations, and to draw attention to some deep-seated and debatable assumptions that implicitly underlie many national and civilisational narratives. Most importantly, imbricated history focuses, not just on interaction across national or 'civilisational' boundaries, but also on the long history of interaction between different social forms: large states and empires, small non-state societies, and migrant communities created (directly or indirectly) through the processes of imperial expansion.

\section{The Mediterranean and the Okhotsk}

In this sense, imbricated history differs from 'inter-civilisational' histories like Fernand Braudel's classic study of the Mediterranean in the age of Philip II. Braudel envisaged the Mediterranean - that sunlit sea whose 'history can no more be separated from that of the lands surrounding it than the clay can be separated from the hands of the potter who shapes it' - and as a meeting place of 'Greek', 'Latin' and 'Islamic' civilisations 
(and an area infused by the less visible presence of a diasporic 'Jewish civilisation'). ${ }^{1}$ Although he was intrigued by the interchange of ideas and material culture between these civilisations, Braudel also repeatedly stressed their underlying durability:

civilizations are transformed only over very long periods of time, by imperceptible processes, for all their apparent changeability. Light travels to them as it were from very distant stars, relayed with sometimes unbelievable delays on the way: from China to the Mediterranean, from the Mediterranean to China, or from India and Persia to the inland sea. ${ }^{2}$

Braudel's civilisations are spatial units - large regions distinguished by allegiance to a supposedly common set of values. But, like all civilisation theories, his view of the past also implicitly rests on a temporal vision of 'civilisation' as the highest in a series of stages of human progress. In this sense, it draws on a tradition (explored in earlier chapters) according to which 'civilisation' is distinguished from earlier phases of 'savagery' or 'barbarism' by the presence of urban settlements, social stratification, centralised organs of government and various technologies such as the art of writing, pottery making, metalworking, etc.

This idea of civilisation has had profound effects on modern historical and social thought. Above all, it focused the attention of the historian on the large states and empires that possess cities and the other hallmarks of the 'civilised'. Civilisation theory thus tended to banish the many small societies that have existed throughout human history to the spatial margins or to the temporal mists of 'prehistory'. Stage theories of history - which assumed a succession of human progress from small huntergatherer communities to agrarian-based tribes, kingdoms and empires and ultimately to industrial modernity - implied that the large number of small-scale, non-agrarian societies still existing in the sixteenth, seventeenth or eighteenth centuries (or more recently) were survivals from the remote past, fossils preserving into modernity the social forms of stone-age 'prehistory'. This view of the world defined such communities as societies without history, whose study (in the modern division of academic labour) was the territory of the anthropologist or prehistorian, not the historian. 'Historical time' thus came to be occupied exclusively

1 Fernand Braudel, The Mediterranean and the Mediterranean World in the Age of Philip II, trans. Sian Reynolds, vol. 1 (London: Collins, 1972), p. 18.

2 Braudel, Mediterranean, p. 773. 
by large-scale, state-organised societies, and small non-state societies appeared on the horizon only when they were conquered or exterminated by expanding nations and civilisations, or when they themselves expanded to the scale of nations.

Braudel's approach to the history of civilisations derived inspiration from these intellectual traditions but developed them in distinctive ways. His vision of the Mediterranean was by no means a narrowly Eurocentric one. He paid great attention to the history and influence of the Turkish empire, as well as to the histories of Spain, France and the Italian city states. But at the same time, his history focused much more on the northern than on the southern shores of the Mediterranean. In particular, the small-scale nomadic societies of North Africa tended to be confined to the fringes of his narrative. This reflected, not only Braudel's interest in the history of 'civilisations', but also his particular (and profoundly influential) understanding of the structure of historical time.

For Braudel, all of historical time was stratified into three levels, simultaneously flowing at three distinct speeds. In the lower depths of history (as it were) lay the stratum of the longue durée, that very slowmoving current of change that shaped landscape, environment and the fundamental elements of human culture. Superimposed upon this was the structural stratum: the stream of time that shaped the political and social order, and in which change could be measured in units of centuries or decades, rather than of millennia. Finally, on the surface of history were the ephemeral waves and eddies of the conjunctural, that stratum of time inhabited by all the crises, triumphs, conflicts, victories and defeats that occupied the attention of most historians, and where change was measured in months and years.

Within this framework, discussion of the small nomadic societies of the southern shores of the Mediterranean is largely limited to chapters dealing with the longue durée - the 'almost timeless' realm of environment - and this discussion is couched in terms that repeatedly evoke the forces of nature. Seen from the inside, Braudel acknowledged, the nomadic societies of the sparsely populated desert areas 'reveal their complicated organisations, hierarchies, customs and astonishing legal structures'. But 'seen from the outside, they seem like a handful of human dust blowing in the wind'. The migrations of these peoples from desert to coast are described, like tides, as 'one of the rhythms of Mediterranean history', although unfortunately for the historian they lack 'the regularity of the 
tides of the seas. ${ }^{3}$ So, while he describes the vibrant power of sixteenthcentury Algiers as one of the corsair capitals of the Mediterranean, Braudel depicts the city as an oasis of civilisation disconnected from its surrounding timeless, cultureless hinterland: during the sixteenth century,

the central Mahgreb, as far as Tiemcen (a city both of Morocco and the Sahara) was amazingly uncivilised. Algiers was to grow up in a country as yet without a leavening of culture, a virgin land, peopled by camel-drovers, shepherds and goatherds. ${ }^{4}$

But dividing time into separate strata inhabited by separate groups of people has curious effects on the way we view history. When the history of indigenous small societies is consigned by the historical imagination to a distinct 'time zone', whether the time zone of prehistory or that of the longue durée, it becomes difficult to conceive of these societies as possessing their own 'structural' and 'conjunctural' history, their own dynamics of change. It also becomes difficult to visualise them as existing simultaneously with spatially contiguous 'historical' states and empires, and indeed as interacting in important ways with these states and empires. Yet it seems fair to suggest that the Mediterranean's small nomadic communities of camel-drovers, shepherds and goatherds existed not only in the slow-moving depths of the longue durée, but also possessed their own 'structural' and 'conjunctural' pasts. Those pasts may be far less easily accessible to the modern historian than the pasts of the Ottoman empire of the Spain of Philip II, but they coexisted with them in that span of time that (for example) modern English-language history labels 'the sixteenth century'.

This issue becomes much more obvious when one turns from the history of a region like the Mediterranean to the history of a region like the Okhotsk Sea. Like the Mediterranean, of course, the Okhotsk is a sea that links as much as it separates human communities: an expanse of water that, in the past, was crossed by complex routes of trade and social communication. But unlike the shores of the Mediterranean, the lands around the Okhotsk Sea are not suited to monocultural agriculture and therefore did not (until very recent times) sustain the dense populations that gave rise to urban life. Most of the communities of the region were small and decentralised, consisting of little self-governing settlements linked to

3 Braudel, Mediterranean, pp. 176-77.

4 Braudel, Mediterranean, p. 772. 
one another by bonds of kinship and ritual, rather than of centralised states. From time to time the power of expanding empires (the Mongol Empire in the thirteenth century, the Qing Empire in the seventeenth and eighteenth centuries, the Russian and Japanese Empires in modern times) exerted an influence over the communities of the region. But the presence of states and empires was more remote, and the part played by small, nonstate societies more important, than in the history of the Mediterranean. To study the history of the Okhotsk region, therefore, it becomes essential to address the history of these small non-state communities.

What might happen if we put this 'hinterland' in the foreground? What would happen if we tried to write an imbricated history from the point of view of the small societies - seeing them always as active participants in history, moving through time alongside their larger neighbours, and interacting with those neighbours and with one another. The picture of history that would emerge would be a very different one: not necessarily a more 'correct' picture, since history always needs to be seen through multiple lenses, but a history in which certain long-neglected features of the past might begin to become visible. The conventional image of human evolution as progressing step by step through stages of hunter-gatherer, herder or agricultural, urban and industrial society would be of little guidance to us, since the societies in question have (as we shall see) not followed such a simple path. Many were based on hunting and gathering or herding, but some (as we shall see) also had histories of crop growing and livestock rearing, and most were engaged in trade of various forms. The societies of Eastern Siberia and the Okhotsk, in other words, have histories in which there is abundant evidence of major social, economic and cultural changes over recent centuries. It is just that this change does not follow the prescribed patterns of stage theories of progress.

\section{Hedgehogs and Foxes}

This view of the past, in other words, brings us face to face with key assumptions that underpinned much modern historical and social thought. In the previous chapters, we have explored some of these assumptions, particularly notions of historical progress and of the emergence of civilisations. Here let us look at some ways in which the history of the Okhotsk region challenges those assumptions, and consider why these challenges may be particularly important in the light of 
profound problems faced by twenty-first-century global society. In the previous chapter we saw how Condorcet's Sketch for a Historical Picture of the Progress of the Human Mind (1795) depicted human knowledge as cumulatively expanding with the growing size and complexity of society. The vision of progress as the creation of ever larger and more centralised knowledge systems was already taking hesitant shape in the axiom of Giambattista Vico (1668-1744) 'first the forests, after that the huts, then the villages, next the cities, and finally the academies', ${ }^{5}$ and persisted in the writings of twentieth-century civilisational theorists from Vere Gordon Childe (1892-1957) to Norbert Elias (1897-1990), and through them exerted a profound influence on modern social theory.

Childe followed Enlightenment thinkers like Condorcet in seeing social progress in terms of ever-expanding human knowledge systems, positing a series of epoch-making technological 'revolutions' - the Neolithic (or agricultural) revolution, the urban revolution and the Industrial Revolution: a schema that provides the basis for many versions of civilisation theory. ${ }^{6}$ Elias's study of the 'civilizing process', meanwhile, focused initially on the impact of social structures on customs and manners. ${ }^{7}$ But in his later years Elias turned increasingly to the role of knowledge, language and symbol in social organisation, for, he observed, one of the most ancient human terrors is:

the horror of not-knowing, the encounter with events for which [we] have no name. Human beings cannot survive if they cannot place events by giving them a name, by fitting them into their fund of communal symbols. ${ }^{8}$

Civilisation thus becomes an exorcism of the unknown by the unending process of naming and classifying. Elias's view of history, like Condorcet's, was one of ever-growing social units with ever more complex knowledge structures:

\footnotetext{
5 Giambattista Vico, The New Science, ed. TG Bergin and M Fisch (Ithaca and London: Cornell University Press, 1968), p. 78. Original published in 1725.

6 Vere Gordon Childe, New Light on the Most Ancient East (London: Routledge and Kegan Paul, 1934); Vere Gordon Childe, What Happened in History, rev. ed. (London: Penguin Books, 1954).

7 Norbert Elias, The Civilizing Process, trans. E Jephcott (Oxford: Blackwell, 1990). Original published in 1939 .

8 Norbert Elias, 'The Retreat of Sociologists into the Present', Theory, Culture and Society 4, no. 2-3 (1987): pp. 223-47, quotation from p. 237, doi.org/10.1177/026327687004002003.
} 
from small bands of twenty-five to fifty members, perhaps living in caves, humans coalesced into tribes of several hundred or several thousand members, and nowadays more and more into states of millions of people. ${ }^{?}$

This was accompanied first by the emergence of specialised priesthoods who held power through their control of esoteric knowledge, and then by the much wider diffusion of scientific knowledge among many specialist groups. ${ }^{10}$

Elias recognised, of course, that human history did not run in a straight line: large, complex societies sometimes dissolved into fragments, as happened in Europe after the fall of the Roman empire. In the long run, though, the 'trend towards bigger survival units is clear'. ${ }^{11}$ Moments of social fragmentation are essentially troughs in the uneven process of social progression - regroupings that prepare the ground for more extensive and complex social integration - and human adaptation to life in ever larger centralised societies becomes the central theme of the social history of the world. Stephen Mennell and others have used Elias's social theories as a basis for understanding the emergence of contemporary global culture. Paraphrasing Elias, Mennell traced the development of humanity from small-scale survival units, in which there could be no specialisation of knowledge, through an ineluctable 'trend ... towards survival units larger and larger both in population and geographical extent' to 'the factual integration of humanity as a whole into a world-wide system of tensions'. ${ }^{12}$

This mapping of expanding knowledge systems, though, overlooks the fact that knowledge may be accumulated in a variety of different ways, which might be imagined as suspended along a range of possibilities between two polar archetypes. One archetype involves the creation of large, centralised knowledge systems of the type sketched by Condorcet, while the other involves the creation of many small decentralised knowledge systems. In the first case, social knowledge comes to be divided between an increasingly complex hierarchy of specialists, and held together by an increasingly formalised system of general axioms. Centralised knowledge

9 Elias, 'Retreat of Sociologists', p. 225.

10 Elias, 'Retreat of Sociologists', p. 225.

11 Stephen Mennell, Norbert Elias: An Introduction (Oxford: Basil Blackwell, 1992).

12 Stephen Mennell, 'The Globalisation of Human Society as a Very Long-Term Social Process: Elias' Theory', in Global Culture: Nationalism, Globalisation and Modernity, ed. Mike Featherstone (London: Sage Books, 1990), pp. 359-71, quotation from pp. 361-62. 
systems are potentially extremely powerful in that they allow very large masses of information to be sorted and classified, allowing the generation of generalised theories of science or social science that may have high levels of predictive accuracy. In the second case - the accumulation of knowledge in small decentralised knowledge systems - there may be relatively little hierarchical division of knowledge or creation of universal rules; instead, human societies divide horizontally into many different small groups that acquire their own intimate experiential knowledge of particular and varied small-scale environments. Here knowledge acquired from neighbouring groups is shaped and deployed precisely in ways that separate and distinguish each group from its neighbours, creating endlessly replicated honeycomb patterns of small-scale difference: endless variations on common themes.

The distinction, in other words, is a little like that suggested by Stephen Marglin, who drew a line between the forms of knowledge he called 'episteme' and 'techne'. 'Episteme', according to Marglin, is analytical, articulate, cerebral, theoretical and professionalised, and it claims to be universally valid. 'Techne', by contrast, is holistic, often implicit, practical and personal; it involves the eye, hand and heart as well as the brain, is derived from tradition and intuition as much as from logical reasoning, and makes no claim to universality. Marglin identified 'episteme' with the aggressively colonising knowledge system of the modern West, and 'techne' with the colonised and rapidly disappearing knowledge systems of 'the Rest' (particularly Asia). ${ }^{13} \mathrm{~A}$ different and perhaps more productive way of looking at things, though, is to suggest that all societies rely on a combination of episteme and techne, but that epistemic knowledge, in one form or another, is a particularly crucial feature of all large-scale, centralised knowledge systems, while small decentralised systems tend to rely more on techne.

In small knowledge systems, where there is relatively little division of knowledge between specialist groups, the relationship between the parts and the whole can remain implicit, to be reimagined and renegotiated

13 Stephen Marglin, 'Losing Touch: The Cultural Conditions of Worker Accommodation and Resistance', in Dominating Knowledge: Development, Culture and Resistance, ed. Frédérique Apfel Marglin and Stephen Marglin (Oxford: Clarendon Press, 1990), pp. 217-82, doi.org/10.1093/ acprof:oso/9780198286943.003.0007; Stephen Marglin, 'Farmers, Seedsmen and Scientists: Systems of Agriculture and Systems of Knowledge', in Decolonizing Knowledge: From Development to Dialogue, ed. Frédérique Apfel Marglin and Stephen Marglin (Oxford: Clarendon Press, 1996), pp. 185-248, doi.org/10.1093/acprof:oso/9780198288848.003.0006; see particularly pp. 226-38. 
through continuous face-to-face contact between the members of the group, and through continuous interaction between people and their lived environment.

Direct experience, generation by generation, feeds back into the tale told. Part of that direct experience is the group context itself, a circle of listeners who murmur the burden back or voice approval, or snore. Meaning flashes from mind to mind, and young eyes sparkle. ${ }^{14}$

There is little need for the recording of formal axioms, or for that generalising of relationships so lovingly described by Condorcet. The strength of such small, techne-based systems lies precisely in their deep perception of the interrelationships within a relatively small surrounding cosmos, and in their sensitivity to the unpredictable, the irregular and the uncertain.

At the opposite end of the imaginary scale, large centralised knowledge systems rely on epistemic knowledge to maintain their coherence. Where knowledge is divided among a large number of specialist groups (priests, philosophers, bureaucrats, craftspeople, scientists) in societies whose size precludes regular face-to-face contact, formal methods of recording, classifying, storing and transmitting knowledge become increasingly important. This is not simply a characteristic of the Greek or JudaeoChristian tradition, but can be seen to some extent in many other large systems. Classical Chinese scientific thought, for example, demonstrates a passion for recording, classifying, labelling and ordering the phenomena of the natural world. Its analytic urge may not entirely coincide with modern concepts of 'rationality' - dragons may be classified with as much care as snakes or bamboos - but it is unmistakably 'epistemic' in Marglin's sense of the word. The strength of such epistemic knowledge systems lies (as Condorcet perceived) in their ability to handle a large number of facts, and to extract from them generalisations about the natural and human world, and therefore above all in their power to comprehend the regular, the repeated and the certain. Metaphorically, we can represent this distinction between episteme and techne in terms of the now famous

14 Gary Snyder, foreword to Songs of Gods, Songs of Humans, by DL Philippi (Tokyo: University of Tokyo Press, 1979), p. vii. 
saying of the poet Archilocus about the wisdom of the hedgehog and the wisdom of the fox: the hedgehog knows one big truth but the fox knows many small truths. ${ }^{15}$

From this point of view, human history (at least until the emergence of the modern global system) can be seen, not simply as the one-way march of 'civilisation', but as a far more complex two-way pull between the creation of centralised and decentralised knowledge systems, and an intricate interplay between the many resulting social forms, in which a multiplicity of knowledge systems coexisted and interacted. Kingdoms and empires expanded, imposing unifying orthodoxies on neighbouring societies. Smaller societies separated themselves from the crumbling edges of imperial systems, domesticating inherited ideas in divergent ways. Migration produced fissures within already small social groups, allowing the separated parts to develop different beliefs and techniques. Large and small societies interacted with one another, exchanging words, stories, rituals and secrets.

The disproportionate attention historians have paid to the growth of large centralised systems has much to do with the fact that these are the systems most likely to leave the monuments and written records whose texts the historian reads. Small societies, lacking these records, tend to be filtered out of the historical vision. Since a number of centralised systems have indeed evolved through a series of roughly comparable (though certainly not identical) technological stages, the tendency has been to generalise these stages into a law of development for all humanity, and consequently to depict smaller societies as remnants of the past, deposited in the frozen realms of an eternal 'prehistory'. As I shall try to show in the sections that follow, an imbricated history approach to the societies of the Okhotsk region can help us to appreciate the historical and contemporary significance of the techne-centred knowledge systems of small societies that operate without centralised state structures.

15 See Isaiah Berlin, The Hedgehog and the Fox: An Essay on Tolstoy's View of History (London: Weidenfeld and Nicolson, 1953). 


\section{Multiple Paths to the Present: The Case of the Okhotsk Region}

The archaeological record shows that this region had experienced many waves of change as communities adapted to climatic shifts, as migrations brought new populations into the Okhotsk seaboard, and as the rise and collapse of states on the fringes of the region altered balances of power. Few of these changes, though, can readily be mapped on the conventional itinerary of social evolution. Instead, shifts between hunting and fishing, herding and crop growing seem to have pursued a meandering course in response to intersecting environmental, social and political forces.

From the fourth to the early first millennium BCE, the lower reaches of the Amur River were inhabited by people who lived in villages close to rivers, lakes or the sea shore, alternating between above-ground summer dwellings and semi-subterranean winter houses. They combined fishing with marine hunting and the raising of dogs, and may also have raised domesticated boars, though evidence for this is controversial. ${ }^{16}$ They made pottery in styles that changed over time. Similar patterns of subsistence existed on Sakhalin Island, and in the south of the island distinctively decorated pottery indicates trade links to Japan during the early Jōmon period (c. 5000-2500 BCE). ${ }^{17}$ Excavations of shell-mounds from the region also show that, 3,000 years ago, the inhabitants of its shoreline were venturing far into the Okhotsk Sea to hunt marine mammals, using harpoons identical to those of the circumpolar peoples of far northern Siberia. ${ }^{18}$ By the early centuries of the common era, new patterns of social activity were becoming evident in the region. In the maritime area, there is evidence that reindeer-herding groups from the west were migrating to the Amur region where they settled and adopted many of the economic and cultural patterns of the local fishing communities. Bronze and later iron implements were becoming common, and crop-growing and pigraising communities spread though many parts of the region, extending as far as the vicinity of today's Vladivostok. ${ }^{19}$ Between the late seventh and

16 Richard Zgusta, The Peoples of Northeast Asia Through Time: Precolonial Ethnic and Cultural Processes Along the Coast Between Hokkaido and the Bering Straits (Leiden: Brill, 2015), pp. 122-24.

17 Zgusta, The Peoples of Northeast Asia, p. 82.

18 MG Levin and LP Potapov, The Peoples of Siberia, trans. S Dunn (Chicago: University of Chicago Press, 1964), pp. 67-68.

19 Hokkaidō Kaitaku Kinenkan, Rosshia Kyokutō Shominzoku no Rekishi to Bunka (Sapporo: Hokkaidō Kaitaku Kinenkan, 1995), p. 4; Zgusta, The Peoples of Northeast Asia, pp. 137-39. 
tenth centuries $\mathrm{CE}$, the southern parts of this region were incorporated into the Balhae (or Bohai) kingdom, a state covering the area that now straddles the frontier between far north-eastern China, North Korea and the Maritime Province of Russia. After incursions by Khitans from the west in 926, the Balhae kingdom collapsed, but in its eastern regions a new centralised state emerged: the Jurchen Jin Empire, which flourished in the twelfth and early thirteenth centuries.

The Balhae kingdom and Jin Empire coexisted with the realm of social and economic interaction now known as 'Okhotsk culture', extending across the southern Okhotsk Sea from the Kurile Islands along the northern coast of Hokkaido to Sakhalin and the mouth of the Amur River between about the third and thirteenth centuries. If you go to the northern Hokkaido city of Abashiri today and walk along the river embankment towards the sea you will find, tucked away between the public library and the fish-processing factories that line the shore, a small park surrounded by high metal railings. Within the park, thick greenery half conceals a complex maze of hummocks and mounds, the remains of the large semi-subterranean houses the people of this place once built to shelter themselves from the intense winter cold. This site, the Mayoro shell-mound, contains one of the most complete remaining villages from the Okhotsk culture era. The Okhotsk peoples, sometimes romantically (and Eurocentrically) referred to as 'Asian Vikings', lived largely from fishing and hunting marine mammals. A glimpse of their long-vanished beliefs is revealed in their graves, each one topped with an inverted pottery vase, and in their beautiful miniature carvings of bears and of human figures with strange pointed headdresses, excavated from this Abashiri site. They were also traders. Their closest mercantile contacts to the south were with the hunting, fishing and farming communities that inhabited all but the northern fringe of Hokkaido, and whose culture is labelled by archaeologists Epi-Jomon (lasting roughly from the third to the seventh century CE), followed by Satsumon (roughly seventh to thirteenth century CE). To the north the trade routes of Okhotsk culture extended as far as the Kamchatka Peninsula. ${ }^{20}$

20 Kikuchi Toshio, 'Ohōtsuka bunka to Nibufu minzoku', Kan Ohötsuku 1 (1993): pp. 1-27; Utagawa Hiroshi, Ainu Bunka Seiritsushi (Sapporo: Hokkaido Shuppan Kikaku Senta, 1988), pp. 274-76. 


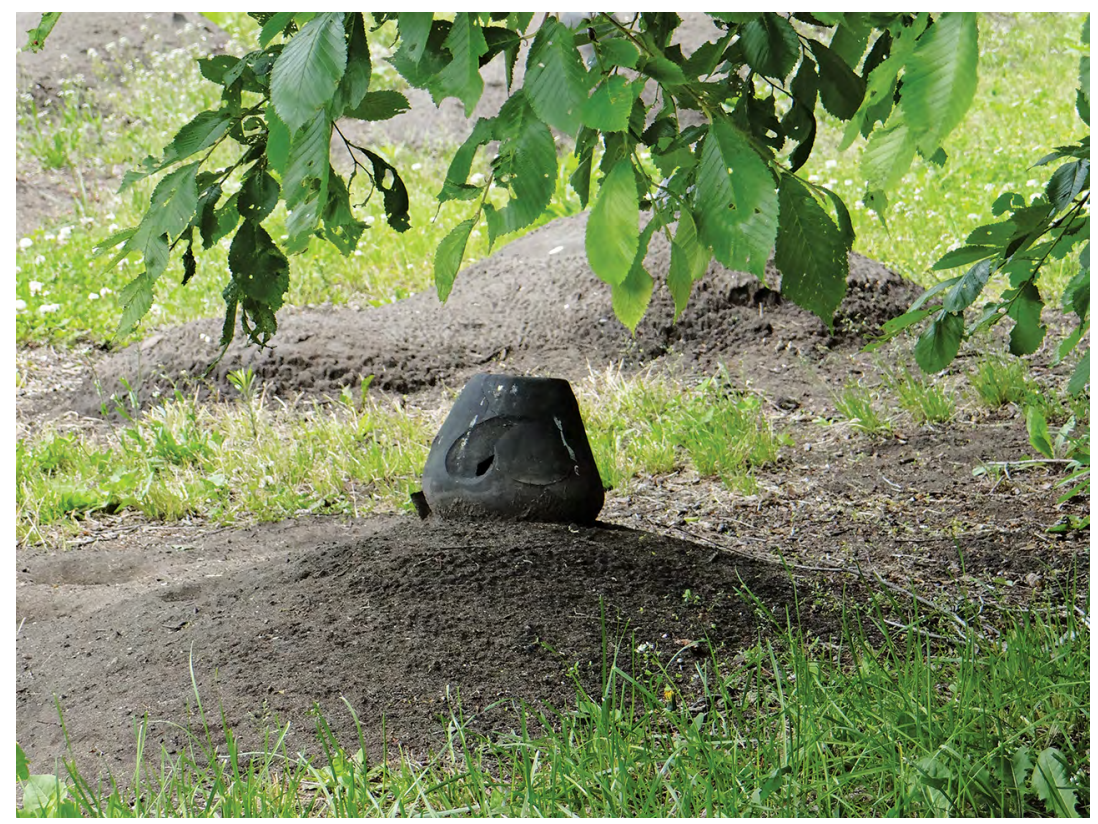

Figure 4.1. Okhotsk culture grave, Abashiri.

Source: Photograph by author.

Okhotsk culture is commonly seen as reflecting a coming together of long-standing indigenous hunting and fishing traditions, forms of marine hunting (including the hunting of whales), which spread throughout the region from the north, and influences from the Amur region and beyond, which included the raising of pigs and the introduction of new designs of pottery. ${ }^{21}$ Within Okhotsk culture itself, though, regional differences existed; for example, archaeological evidence shows that pigs were raised in Okhotsk culture areas in Sakhalin and western Hokkaido, but not in sites on the eastern seaboard of Hokkaido. ${ }^{22}$ Trading links connected the Okhotsk culture area to the coastal societies of mainland Asia, and it seems likely that it was this area to which a Tang Dynasty Chinese chronicler referred when he described the arrival at the imperial court of an emissary from a land where:

21 Zgusta, The Peoples of Northeast Asia, pp. 83-84.

22 Mark J Hudson, 'The Perverse Realities of Change: World System Incorporation and the Okhotsk Culture of Hokkaido', Journal of Anthropological Archaeology 23 (2004): p. 296, doi.org/10.1016/ j.jaa.2004.05.002. 
the people live scattered on the various isles. There are many moors and marshes. The land is favoured with plenty of fish and salt. It grows cold quite early and is frequently visited by a heavy frost and snow. With their feet strapped to the wooden pieces 6 inches wide and 7 feet long [i.e. skis], the people walk on the ice and chase running animals. The land abounds in dogs whose skins are made into skin-garments. It is a custom to wear long hair. ${ }^{23}$

The extensive trading networks that spanned the Okhotsk Sea, linking its southern inhabitants to China and also to the fishing and marine-hunting communities to the north, are evident from the fact that Chinese coins of this period have been found not only at sites in northern Hokkaido but even as far afield as Sredniya, near the northern end of the Kamchatka Peninsula. ${ }^{24}$ On the northern and eastern shores of the sea, meanwhile (as the researches of Il'ia Gurvich showed), the peoples of Kamchatka, Chukotka and Alaska came into contact through hunting expeditions, and developed trading links which enabled them to exchange valuable resources and artefacts. ${ }^{25}$

From about the thirteenth century onwards, patterns of daily life and cultural interaction in the Okhotsk region were transformed. The reasons for the historical shift are not obvious, but it is likely that important triggers included Mongol incursions into the Lower Amur region and Sakhalin in the late thirteenth century. ${ }^{26}$ Climatic change may also have had a part to play, along with the northward expansion of Japanese influence into the south of Hokkaido. ${ }^{27}$ Whatever the causes, some economic activities (like the keeping of domestic pigs) disappeared from most of the region, while others (like inland hunting) became more important. Throughout Hokkaido, the production of pottery began to disappear, and the pattern of life archaeologists and anthropologists describe as 'Ainu culture', in which fishing and forest hunting played a particularly important role, took shape, influenced by a confluence of the legacies of Okhotsk and Satsumon cultures.

23 Quoted in S Wada, 'The Natives of the Lower Reaches of the Amur River as Represented in Chinese Records', Memoirs of the Toyo Bunko 10 (1938): pp. 41-102, quotation from p. 52.

24 Kikuchi Toshio, 'Ohōtsuka bunka'.

25 Il'ia S Gurvich, 'Interethnic Ties in Far Northeastern Siberia', in Anthropology of the North Pacific Rim, ed. William W Fitzhugh and Valerie Chaussonnet (Washington DC and London: Smithsonian Institution Press, 1994), pp. 309-20.

26 John Stephan, Sakhalin: A History (Oxford: Clarendon Press, 1971), pp. 20-21.

27 Ben Fitzhugh, E Gjesfjeld, W Brown, MJ Hudson and Jennie D Shaw, 'Resilience and the Population History of the Kuril Islands, Northwest Pacific: A Study in Complex Human Ecodynamics', Quaternary International 419 (2016): pp. 165-93, doi.org/10.1016/j.quaint.2016.02.003. 
'Ainu culture' is sometimes seen as being characterised by an absence of ceramics, but in fact archaeological evidence shows that pottery making continued in some areas until quite recent times. Excavations in southern Sakhalin reveal large amounts of pottery fragments mixed with the remains of tobacco pipes, showing that these date to a period after the introduction of tobacco to the region in the sixteenth century. ${ }^{28}$ One prewar excavation also yielded pottery fragments decorated with the imprint of bears' feet alongside fragments decorated with a pattern clearly made by the cog-wheel of a clock. ${ }^{29}$ Another characteristic of Ainu culture in both Hokkaido and Karafuto was the development of weaving techniques using looms, which the French explorer La Pérouse described in the 1780 s as looking 'absolutely similar to ours'. ${ }^{30}$

During this period, connections across the Okhotsk Sea seem to have diminished, but links between the north-west of Hokkaido, western Sakhalin and the Amur River region intensified. It was also perhaps around this time that reindeer herding was introduced to Sakhalin by migrants from the Siberian mainland (ancestors of the people later known as Uilta). ${ }^{31}$ The Qing Dynasty established a series of trading posts along the Amur, and by the 1730s were extending their influence across the Tartar Straits into Sakhalin, appointing prominent villagers on the west coast to the positions of 'clan chief' (hala $i d a$ ) and 'village chief' (gasan $d a$ ), in which capacity they were responsible for collecting furs to be taken as tribute to the Amur trading posts (discussed further in the following chapter). This system encouraged the close interaction between the Ainu and Nivkh-speaking villagers of western Sakhalin and the indigenous communities of the Amur region, which lasted into the early nineteenth century. ${ }^{32}$

28 Saharin Kōkogaku Kenkyūkai, ed., Karafuto Nishikaigan no Köko Shiryō (Obihiro: Saharin Kōkogaku Kenkyūkai, 1995).

29 Oka Masao and Baba Osamu, 'Kita Chishima Shumushutō oyobi Karafuto Taraika Chihō ni okeru Kōkogakuteki Chōsa Hōkoku', Minzokugaku Kenkyū 4, no. 3 (1938): pp. 489-552.

30 Jean-François de Galaup de La Pérouse, The Journal of Jean-François de Galaup de La Pérouse, trans. and ed. John Dunmore, vol. 2 (London: The Hakluyt Society, 1995), p. 292.

31 Zgusta, The Peoples of Northeast Asia, p. 156; Yoshiko Yamada, 'A Preliminary Study of Language Contacts around Uilta in Sakhalin', Hoppó Bunka Kenkyü 3 (2010): pp. 59-74, reference from pp. 62-63.

32 Sasaki Shirō, 'Amūru-gawa Shimoryūiki Shominzoku no Shakai, Bunka ni okeru Shinchō Shihai no Eikyō ni tsuite', Kokuritsu Minzoku Hakubutsukan Kenkyū Hökoku 14, no. 3 (1989): pp. 671-771. 
None of this suggests the stagnation of societies trapped in the timeless mists of prehistory. On the contrary, the picture is one of rather rapid economic change and dynamic interaction between many small social groups. At the same time, though, this change does not readily fit the image of 'progress' depicted by nineteenth-century theory. Some aspects of change - the diffusion of techniques like reindeer herding and weaving, the development of new trading links and specialised centres of boat production, etc. - match definitions of 'progress', while others - the disappearance of pig farming and the decline of pottery production could in conventional terms be seen as a 'relapse' towards a lower stage of development. To put it another way, the story of Okhotsk history raises questions about the usefulness of conventional trajectories of social and economic 'progress' in charting the long pre-modern experiences of small-scale communities living in areas unsuited to dense settlement and intensive agriculture.

An area like the Okhotsk seaboard, with its extreme climate where temperatures regularly fall below minus 20 degrees Celsius in the winter and where land that is hard in winter turns to impassable marsh in summer, is ill-adapted to large-scale monoculture. Survival in this environment requires patterns of settlement and economic activity that shift with the seasons, and the deep knowledge of small local environments that enables humans to make the best use of scarce food resources. ${ }^{33}$ Small climatic variations are likely to have had a very large impact on patterns of human existence. Climate variation not only affected the frontiers of crop growing and the availability of fodder for domestic animals like pigs and reindeer; it also had a dramatic effect on human communications. In much of the region, the quickest form of transport was by ski or dog sled over snow or frozen sea. The cold months of the year were the main time for trading journeys or for travelling to arrange marriages with distant clans. Every winter, small islands ceased to be islands and places like Sakhalin 'became' part of the Asian continent. A slight rise in winter temperatures could make a large difference to the area of sea or river that could be traversed in winter, drastically affecting regular travel routes. In this environment, the ability of societies to adapt swiftly from one form of subsistence to another, and to reorganise their social interrelationships, was at a premium.

33 See, for example, Tat'yana Roon, Uil'ta Sakhalina: Istoriko-Etnografucheskoe Issledovanie Traditsionnovo Khozyaistva i Material'noi Kul'tury XVIII - Serediny-XX Vekov (Yuzhno-Sakhalinsk: Sakhalinskoe Oblastnoe Knizhnoe Izdatelstvo, 1996). 
The societies of the Okhotsk, then, needed to adapt both to environmental change and to fluctuating relationships with large, centralised societies to the south and west. Existing on the very outermost fringes of the Chinese world, they were subject to the waxing and waning pull of mainland Asian states, as kingdoms and dynasties rose and fell. When the Balhae kingdom, Jurchen Jin Empire, the Mongol Empire or the Manchu Qing Dynasty were at their most powerful, communities along the fringes of the Okhotsk Sea were drawn into trading and tributary relationships that were sometimes exploitative, but at times also allowed them to exchange the rare products of their region (particularly furs) at high prices. As these centralised kingdoms declined, on the other hand, trade links to the mainland atrophied, and the Okhotsk societies were forced to rely more on production for subsistence (fishing, dog farming, reindeer herding, craft production, etc.), or on trade among the small, non-state societies of the region. Recent research on the archaeology of the Kurile Islands, for example, suggests that, while the fourteenth-century onset of the socalled Little Ice Age may have been a factor in the decline of the islands' population around the end of the Okhotsk culture era, another factor was probably the erosion of trade contacts with neighbouring societies as a result of shifts in the East Asian international order. ${ }^{34}$ Surviving such changes required the flexibility to shift emphasis from one part of the productive system to another - in some eras, devoting more time to hunting and long-distance trade, in others spending more energy on fishing, local trade, craft production and (in certain areas) crop growing.

Complex patterns of overlapping social networks probably helped to sustain this economic flexibility. In areas like the central parts of Sakhalin, for example, Nivkh and Uilta villages were often close to one another, and some villages were made up of inhabitants belonging to more than one language group. ${ }^{35}$ The language groups developed cultural practices that allowed both sharing of some forms of knowledge and economic differentiation, enabling different groups to make use of different parts of the natural environment. Uilta, for example, hunted marine mammals in summer and forest animals in winter, but also made use of forest resources

34 Fitzhugh et al., 'Resilience'.

35 See, for example, Bronislaw Piłsudski, 'B. O. Pilsudski's Report on his Expedition to the Ainu and Oroks of the Island of Sakhalin in the Years 1903 to 1905', in The Collected Works of Bronislaw Pitsudski, vol. 1, The Aborigines of Sakhalin, ed. Alfred F Majewicz, Trends in Linguistics Documentation 15-1 (Berlin and New York: Mouton de Gruyter, 1998), pp. 192-221, doi.org/ 10.1515/9783110820768-013. 
such as summer grass, mosses and lichens as food for their reindeer herds, while Nivkh living in neighbouring areas focused more intensively on fishing.

Although there was oral history evidence of past conflicts between these groups - particularly between the Ainu and Uilta - a modus vivendi developed over time that allowed diverse language groups to share the same ecological space while adopting and adapting techniques from one another. An interesting example of the continuous processes of technological innovation and interaction was cited by the Polish scholar Bronislaw Piłsudski, who noted in the early twentieth century that, as whaling expanded in Sakhalin, Ainu communities started to use whalebone as runners for their dog sleighs. This practice was then taken up by the Uilta neighbours for their reindeer sleighs, but the Uilta soon found that reindeer appeared to have a negative reaction to the smell of whalebone, so they reverted to the use of wooden sleigh runners. ${ }^{36}$

Marriage between members of different language groups seems to have been common. In these multilingual communities, villagers cooperated in productive tasks and also probably shared some ritual activities. But members of each language group also possessed ritual and kinship ties that linked them to other members of their own language community, often in distant parts of the island, or as far away as the Siberian mainland. Russian naturalist and geographer Leopold von Schrenck, for example, described the scene on the Tymy (or Tym) River in central Sakhalin, which he visited in 1856:

The Gilyaks [Nivkh] of the Tymy collect immense stores of frozen fish, not only as food for themselves and their dogs during the winter, but also as an object of trade with the Ainos, Oronchons [Uilta], the Gilyaks [Nivkh] of the coast, the mainland, the Ainan and the Manguns on the Amur. The Ainos bring to the valley of the Tymy Japanese goods, the Oroke furs, the others copper, seals, Russian and Manchu merchandise. ${ }^{37}$

36 See Bronislaw Piłsudski, 'From the Report on the Expedition to the Orok in 1904', in The Collected Works of Bronislaw Pitsudski, pp. 618-77, reference from pp. 642-43, doi.org/10.1515/97831108 20768.

37 Quoted in EG Ravenstein, The Russians on the Amur (London: Trübner and Co., 1861), p. 273. 


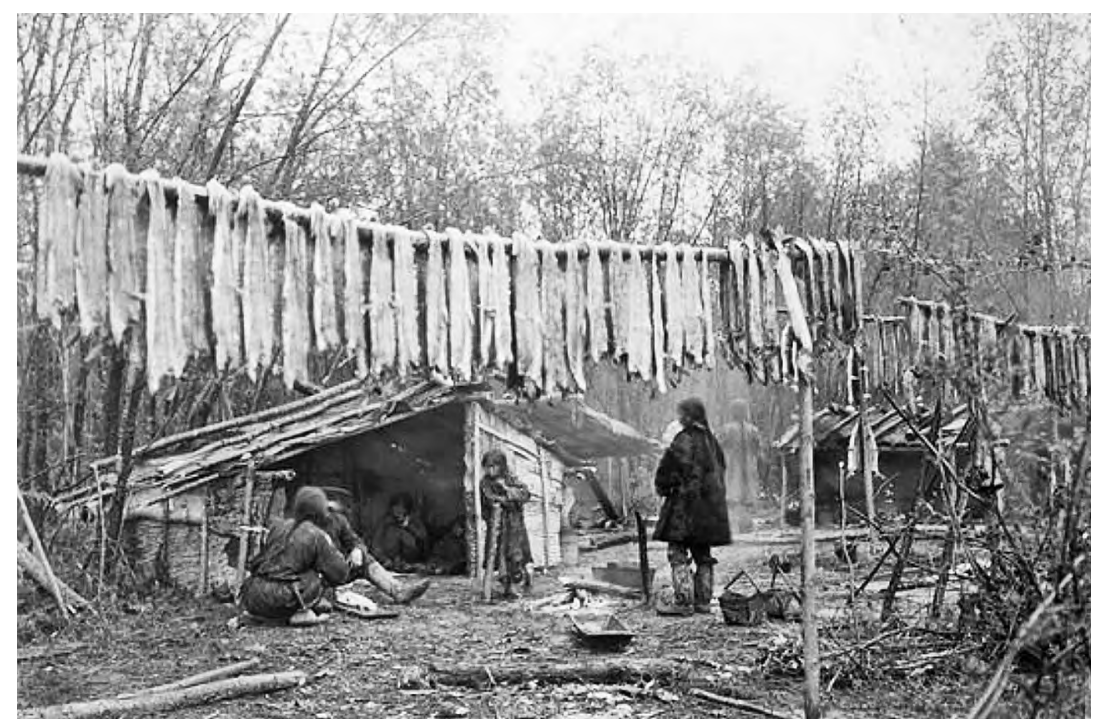

Figure 4.2. Nivkh drying fish, early twentieth century.

Source: Wikimedia commons, public domain.

By mobilising intersecting and often geographically extended social networks, the people of the region would more readily have been able to adjust to a world where repeated realignments of trading patterns and subsistence activities were needed.

\section{A Problem of Progress}

I have described imbricated history as dealing with the intersections between large and small societies, but of course the distinction between large- and small-scale social systems is itself a matter of ideal types. In the real world, the picture has been one of infinitely complicated local particularities, hybridities, imperial expansions and interactions. In times of Chinese imperial expansion some groups on the fringes of the empire were fairly thoroughly absorbed into the North Chinese or Manchu social and cultural world, while other societies were more loosely drawn into the imperial orbit - as in the seventeenth century, the Nanai, Ul'chi, Nivkh and Ainu peoples of the Lower Amur and Sakhalin were subjected to a tributary relationship with China. This link exposed the societies of the region to the influence of Chinese and Manchu goods, 
techniques, designs and social systems (including the creation of new village power structures), but left much of the underlying substructure of local knowledge unaltered.

On the other hand, the centralising pull of the Chinese empire was balanced by the fragmenting pull of human migration. Small groups repeatedly split off from established settlements, moving into new territory where they gradually developed distinctive dialects, legends and ways of life. So the reindeer-herding community now known as the Uilta who probably migrated to Sakhalin from Eastern Siberia sometime before the seventeenth century were, by the nineteenth century, far enough removed from their continental roots to be classified by anthropologists as a distinct 'ethnic group'. These processes of dispersal continued until quite recent times: the social group known as the Even, living mostly along the western shores of the Okhotsk Sea, seem to have developed the dialect and myths that distinguish them from their neighbours, the Evenk, in the period since the early eighteenth century.

Meanwhile, of course, many of the peoples of the region had begun to be exposed to the technological and social influences of newly emerging imperial systems: Russia in the west and Japan in the south. The Japanese influence became particularly powerful from the eighteenth century onward. Throughout the Tokugawa period (1603-1868), the island then known as Ezo (Hokkaido) was divided, with a small region to the southwest (the peninsula in the lower left corner of the map in Figure 4.3, known as Wajin-Chi or Matsumae-Chi ${ }^{38}$ ) being placed under the direct control of the Japanese Matsumae Domain and settled by migrants from other parts of Japan, while in the remainder of the island (Ezo-chi), Ainu continued to live a more or less independent existence. In the second half of the eighteenth century, though, Ainu society was increasingly affected by influences from Matsumae Domain, as Japanese fishing concerns were licensed to set up ventures along the shores of Ezo-chi as far as southern Sakhalin and the southern Kurile Islands. Meanwhile, the Matsumae domain lords were also placing increasing demands for 'tribute' on the indigenous population. ${ }^{39}$

38 Literally 'Matsumae Territory' or 'Japanese Territory'.

39 See, for example, David L Howell, Capitalism from Within: Economy, Society and the State in a Japanese Fishery (Berkeley and London: University of California Press, 1995); Brett Walker, The Conquest of Ainu Lands, 1590-1800 (Berkeley and London: University of California Press, 2001). 


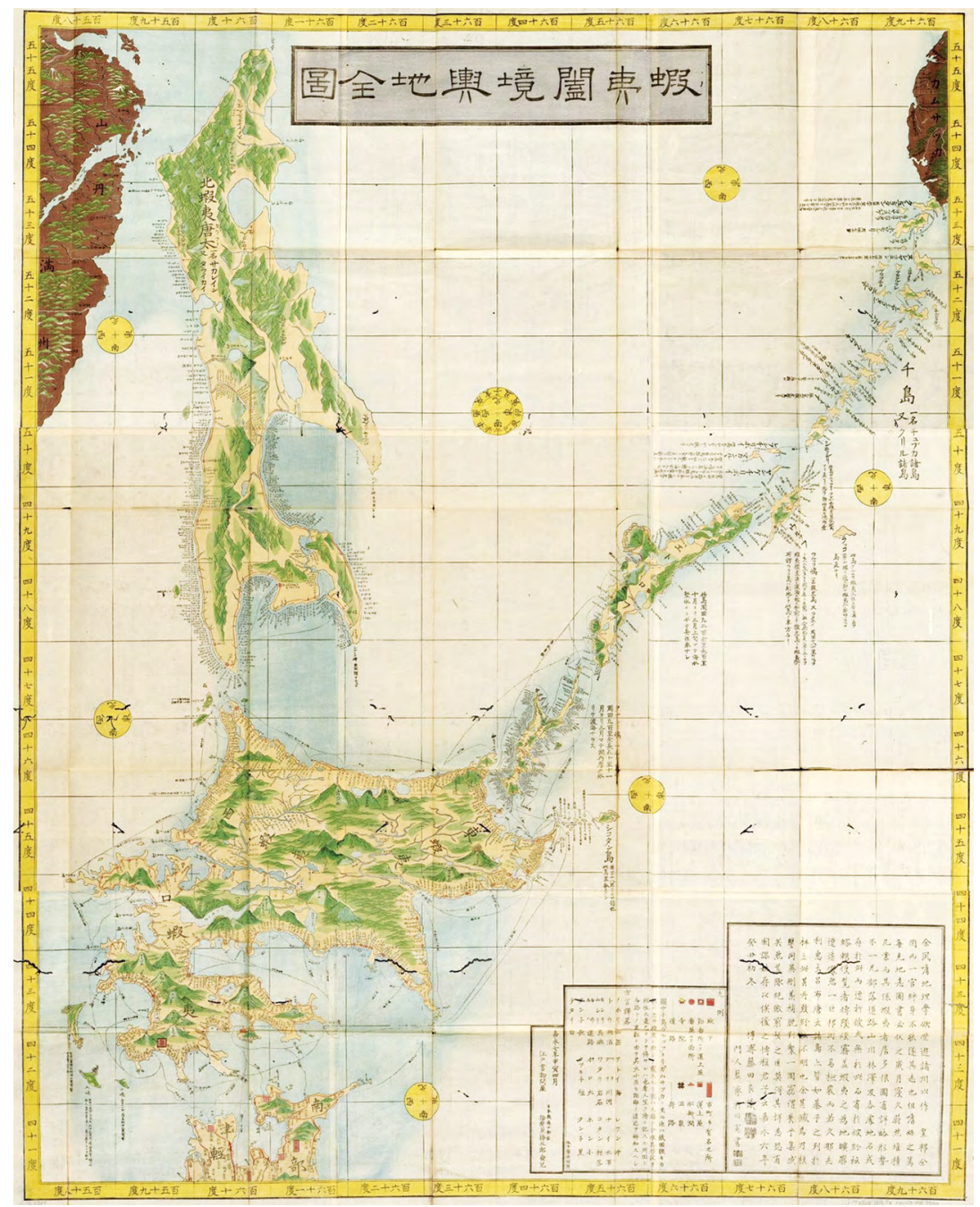

Figure 4.3. 1807 map of Ezo.

Source: Fujita Tonsai and Hashimoto Ransai, 'Ezo Kōkyō Yochi Zenzu', Library of Congress Geography and Map Division, Washington DC. 
The violence that is done to the history of this region by trying to fit it in to stage theories of human development is well illustrated by the vexed question of the place of farming in Ainu society. In historical times, Ainu societies relied on hunting, fishing and the collection of shellfish and plants for a large part of their diet, but there is also abundant archaeological, documentary and ethnographic evidence to show that they practised at least two forms of farming. The first was dog farming, an activity that formed the basis of the Sakhalin Ainu economy (and also seems to have been practised on a smaller scale in other parts of Ainu territory). Perhaps because dogs play a very different role both in European and the Japanese society, the Ainu techniques of dog breeding are seldom recognised as 'farming', yet all the available information suggests that for the Sakhalin Ainu dogs played very much the same role that cows or camels play in other societies; in other words, they provided food and clothing and acted as draft animals. In addition, of course, they were important companions in the hunt. ${ }^{40}$

Japanese official Mamiya Rinzō, who travelled through Sakhalin in 1807-09, describes each well-to-do Ainu family as owning between five and 13 dogs, who were selectively bred, and fed and trained with great care. Small and weak dogs were killed for their meat and hides, while the stronger dogs were used to pull sleds and boats. Sakhalin Ainu had welldeveloped veterinary techniques, which were used, for example, when castrating sled dogs - a practice said to make them stronger. Good-quality dogs were greatly valued and traded for high prices. ${ }^{41}$ As well as their use as food and beasts of burden, Cornelis Coen records that the dogs were trained to catch salmon from the rivers, and that they would tear off and eat the fish head and carry the rest of the carcass back to their owner's house. ${ }^{42}$

40 Takakura Shinichirō. Shinpan Ainu Seisakushi (Tokyo: San-Ichi Shobō, 1972), p. 31; see also Chuner M Taksami, 'Traditional Culture of the Peoples of the Russian Pacific Coast', in Fitzhugh and Chaussonnet, Anthropology of the North Pacific Rim, pp. 275-80 (particularly p. 278).

41 Mamiya Rinzō, 'Kita Ezo Zusetsu or a Description of the Island of Northern Yezo by Mamiya Rinsō', trans. John A Harrison, Proceedings of the American Philosophical Society 99, no. 2 (1955): pp. 93-115, reference from pp. 104-06. Original published in 1855.

42 PA Leupe, ed., Reize van Maarten Gerritszoon Vries in 1643 naar het Norden en Oosten van Japan Volgens het Journaal Gehouden door C. J. Coen (Amsterdam: Frederik Muller, 1858), p. 131. 


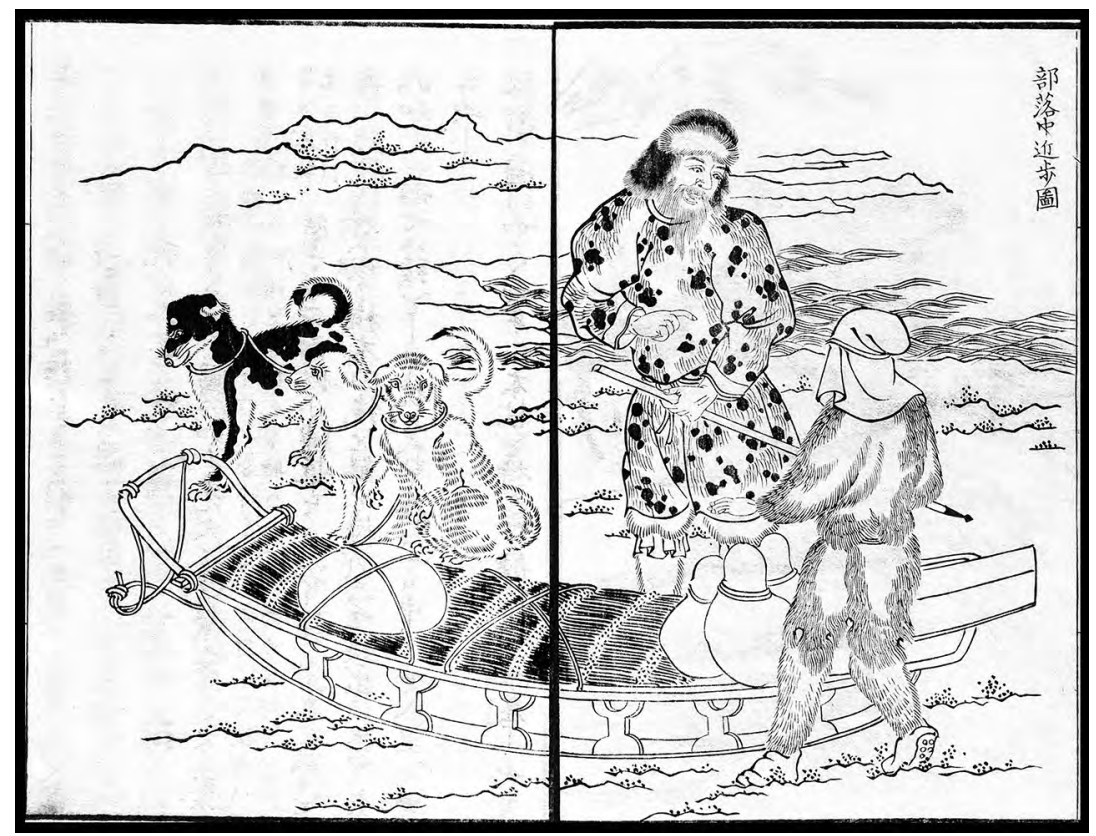

Figure 4.4. Ainu with dog sleigh.

Source: Mamiya Rinzō, 'Kita Ezo Zusetsu or a Description of the Island of Northern Yezo by Mamiya Rinsō', trans. John A Harrison, Proceedings of the American Philosophical Society 99, no. 2 (1955). Originally published in 1855.

The second form of farming involved the more familiar activities of cultivating grains and vegetables. Crops seem to have included barley, wheat, sorghum, millet and beans; some rice was also found, though this was probably imported. A number of Tokugawa texts include references to Ainu crop production, and the subject has also been researched in some detail by scholars like Takakura Shinichirō and Hayashi Yoshishige. ${ }^{43}$ Work in the fields was generally carried out by women, who, throughout the summer months, would rise early and spend the morning tending their crops. Small fields were cleared along the banks of rivers, with the cut grasses and weeds being burnt to provide ash as fertiliser. These fields would be cultivated for two or three years, and then allowed to return to forest. Once the seeds had been sown no fertiliser was used and fields

43 Takakura, Shinpan Ainu Seisakushi; Hayashi Yoshishige, Ainu no Nōkō Bunka (Tokyo: Keiyūsha, 1969). 
were only occasionally weeded, but before planting seeds were sometimes soaked in a mixture of bird's egg and extracts of various plants, which was believed to encourage germination. ${ }^{44}$

Over the past two decades, archaeologists have recognised and researched the role of crop growing in a historically dynamic and changing Ainu culture. ${ }^{45}$ This shift in perspectives is part of a broader rethinking of the vision of the 'Neolithic revolution', and a growing acknowledgement of more complex and diverse historical processes of change from one pattern of subsistence to another. ${ }^{46}$ Yet standard accounts of Japanese society still quite frequently present Ainu primarily in terms of immutable genetic connections to Japan's earliest population, as embodiments of 'the Jōmon origins of Japan' ${ }^{\text {'47 }}$ and being 'on the brink of extinction'. ${ }^{48}$ This interpretation blurs the important distinction between genetics and culture: the fact that people who identify themselves as Ainu today may have DNA links to Jōmon ancestors (as well as to peoples of Eastern Siberia) does not make Ainu culture a survival of Jōmon culture, any more than the Scandinavian DNA found in many British people today makes contemporary British culture a survival of Viking culture. Part of the reason why this image of the Ainu has been so hard to shift, I believe, lies in the fact that the history of Ainu farming radically contradicts various deeply rooted modern intellectual paradigms that have sometimes become entirely invisible to observers.

In the first place, the very existence of Ainu farming upsets the attempts that a number of Japanese scholars have made to construct the Ainu as preservers of the most ancient known form of Japanese culture. This view, for example, was energetically proposed by philosopher Umehara Takeshi, who saw Jōmon as being the crucible of Japanese culture, and argued that

44 Hayashi, Ainu no Nōkō Bunka; Matsuura Takeshirō, Sankō Ezo Nisshi, vol. 2 (Tokyo: Yoshikawa Kōbunkan, 1971), pp. 51-52. Original written in 1850.

45 See, for example, Yuriko Fukasawa, Ainu Archaeology as Ethnohistory: Iron technology among the Saru Ainu of Hokkaido, Japan, in the 17th century (Oxford: British Archaeological Reports, 1998); Gary W Crawford, 'The Jomon in Early Agriculture Discourse: Issues Arising from Matsui, Kanehara and Perason', World Archaeology 40, no. 4 (2008): pp. 445-65, doi.org/10.1080/00438240802451181; Hideyuki Ōnishi, 'The Formation of the Ainu Cultural Landscape: Landscape Shift in a HunterGatherer Society in the Northern Part of the Japanese Archipelago', Journal of World Prehistory 27, no. 3-4 (2014): pp. 277-93, doi.org/10.1007/s10963-014-9080-2.

46 Junzo Uchiyama, JC Gillam, LA Hosoya, K Lindström and Peter Jordan, 'Investigating Neolithization of Cultural Landscapes in East Asia: The NEOMAP Project', Journal of World Prehistory 27, no. 3-4 (2014): pp. 197-223, doi.org/10.1007/s10963-014-9079-8.

47 Ken Henshall, A History of Japan: From Stone Age to Superpower, 3rd ed. (Basingstoke and New York: Palgrave Macmillan, 2012), p. 12.

48 Roger J Davis, Japanese Culture: The Religious and Philosophical Foundations (Tokyo: Tuttle Publishing, 2016), p. 16. 
the Ainu had preserved Jōmon hunter-gatherer culture into the modern era in a particularly pure form. ${ }^{49}$ An alternative version, put forward by Hayashi Yoshishige (one of the first Japanese scholars to write extensively about Ainu crop-growing practices) suggests that Ainu society was a survival not of Jōmon hunter-gatherer culture, but of the very earliest form of Japanese agricultural society, associated with the Yayoi to Kofun periods (around 200-500 CE). Hayashi wrote:

It is recognized ... that Ainu material culture was influenced to no small degree by Japanese Yayoi and Kofun period culture. One typical example is the impact of farming. The Ainu being a static hunter-gatherer people, we can say that they preserved this Yayoi and Kofun period Japanese farming almost unchanged until modern times. ${ }^{50}$

So, having provided a careful and fascinating description of the nature of Ainu farming techniques, Hayashi then felt impelled to go on to demonstrate that these techniques were similar to techniques found in Japan, but - since the Ainu were a 'static hunter-gatherer people' - always more primitive than anything to be found in historical Japanese society. ${ }^{51}$

But this picture of Ainu society as a culture trapped forever on the brink of an 'agricultural revolution' presents problems. For one thing, despite Hayashi's emphasis on differences between Ainu farming and modern Japanese techniques, Ainu farm practices were remarkably like forms of farming practised in certain parts of Japan at least until the late eighteenth century. For example, Japanese Tokugawa-period settlers in Matsumae-Chi, whose small-scale farming activities were described by Mogami Tokunai in the 1780 s, also practised shifting cultivation. They too cleared small fields, abandoning them after three to five years, and like Ainu farmers did not fertilise the soil (despite the abundance of locally produced fertiliser) or devote effort to weeding. These farming practices, besides, were not unique to the far north, for one farmer whom Mogami interviewed in Ezo came from the island of Sado off the western coast of Japan, and said that the same techniques were used in his home district. ${ }^{52}$ Indeed, similar forms of shifting cultivation are known to have existed in many parts of Japan until relatively recent times.

49 See, for example, Umehara Takeshi and Hanihara Kazurō, Ainu wa Gen-Nihonjin ka (Tokyo: Shōgakukan, 1982).

50 Hayashi, Ainu no Nōkō Bunka, p. 3.

51 Hayashi, Ainu no Nōkō Bunka, pp. 175-88.

52 Mogami Tokunai, Ezo Söshi, reprinted in Hokumon Sösho, ed. Ōtomo Kisaku, vol. 1 (Tokyo: Kokusho Kankōkai, 1972), pp. 326-27. Original written in 1790. 
Japanese farmers in Matsumae-Chi and Sado would surely have known about the more intensive farming techniques used in other parts of Japan, and the fact that their crop production was similar to that of the Ainu suggests a rather different interpretation of this form of shifting cultivation: an interpretation that is borne out by Japanese official Sakakura Genjirōs observations of the region in the 1730s. Sakakura commented that farming was uncommon in even in the Japanese-settled area of Ezo, not because the soil was poor, but because the main farm season coincided with the summer months when herring swarmed in vast shoals off the coast. The lucrative herring fisheries drew labour away from farming, and made the very labour-intensive forms of farm production employed in most other parts of Japan impractical. In fact, Sakakura implied that farming had at one stage been attempted on a larger scale in region, but that, because of the wealth to be won from the fisheries 'the people have long since ceased to attempt farming..$^{53}$ In the light of these comments, it seems likely that the types of crop production practised by the Ainu and by Japanese communities in Ezo and Sado were not simply a primitive survival of the past, but were techniques specifically developed to suit societies where a large amount of time was taken up with fishing or hunting activities. Small-scale, shifting cultivation with very little weeding, fertilising and irrigation would have made good sense in area where land was abundant and labour scarce.

This close interrelationship between farming and fishing activities had crucial implications for the fate of Ainu farming during the Tokugawa period. For the fact is that, as the archaeologist Fukasawa Yuriko puts it 'Ainu culture is defined rather by the disappearance of cultivation than by its existence'..$^{54}$ While there is substantial archaeological evidence for farming in earlier centuries, signs of crop growing seem to become more and more elusive in the middle to late Tokugawa period. The increasing incorporation of Ainu labour (both male and female) into the herring fisheries almost certainly had much to do with this disappearance. When Sakakura Genjirō visited the region in the 1730s, he remarked that farming was carried out by Ainu living in the mountain areas, but not by

53 Sakakura Genjirō, Ezo Zuihitsu, reprinted in Hoppō Mikōkai Komonjo Shūsei, ed. Terasawa Hajime et al., vol. 10 (Tokyo: Sōbunsha, 1979), p. 77. Original written in 1739.

54 Yuriko Fukasawa, 'Emishi and the Ainu' (paper presented at the international symposium Japanese Archaeology in Protohistoric and Early Historic Period: Yamato and its Relations to Surrounding Populations, University of Bonn, 1992). 
those on the coast. The extent of farming by coastal Ainu in earlier periods is not clear, but the penetration of Japanese fishing activities into the area undoubtedly discouraged cultivation.

At times, this may have been a simple question of 'comparative advantage': catching fish for the Japanese may indeed have been more profitable than the uncertain process of producing a small harvest of grain or vegetables. But, as is often the case in economic history, comparative advantage was, where necessary, backed up by force. As Matsumae's revenue became increasingly dependent on Ainu labour in the herring fisheries, so it became essential for Ainu farming activities to be discouraged. Mogami Tokunai noted that by the late eighteenth century the import of seeds from Matsumae to Ainu territory was prohibited, ${ }^{55}$ while another Edo text provides a fascinating comment on the reason why Ainu farming was carried out in remote mountain valleys rather than near to their villages: it was '(1) so that they [the farm fields] are not troubled by thieves; (2) because when the Japanese come to trade they object that [crop growing] prevents fishing and suppress it ${ }^{56}$ The same story is told by Matsuura Takeshirō, an unusually observant and sympathetic Japanese traveller who visited the remoted parts of Ezo-chi in the mid-nineteenth century. Matsuura heard complaints from local village leaders that efforts to cultivate crops - particularly crops such as tobacco and hemp - invariably evoked reprisals by officials from Japanese trading posts, who feared that farming might reduce the reliance of Ainu on imported Japanese products and on wage labour in the Japanese fisheries. ${ }^{57}$ Anthropologist Deriha Kōji has also pointed out that Ainu hunting activities were intensified by growing pressure from Matsumae Domain, which demanded that Ainu communities provide 'tribute' in the form of animal pelts. In particular, after 1812, Matsumae strictly enforced its demands for small animal pelts from the Ainu, and used these for its own trading activities with indigenous communities of the Lower Amur region. ${ }^{58}$

55 Mogami, Ezo Söshi, p. 315.

56 Quoted in Hayashi, Ainu no Nōkō Bunka, p. 26, emphasis added.

57 See Hanasaki Kōhei, Shizuka na Taichi (Tokyo: Iwanami Shoten, 1993), p. 79.

58 Deriha Kōji, 'Kinsei Makki ni okeru Ainu no Kegawajū Shuryō ni tsuite: Kegawa Kōeki no Shiten kara', Senri Ethnological Reports 34 (2002): pp. 97-163; Deriha Kōji, 'Trade and Paradigm Shift in Research on Ainu Hunting Practices', in Beyond Ainu Studies: Changing Academic and Public Perspectives, ed. Mark J Hudson, Ann-Elise Lewallen and Mark K Watson (Honolulu: University of Hawai'i Press, 2014), pp. 136-49, doi.org/10.21313/hawaii/9780824836979.003.0009. For further discussion of the impact of Matsumae's economic policies on the Ainu population, see Howell, Capitalism from Within, particularly Chapter 2 . 
De-agrarianisation was also caused by other, less obvious factors. Inland Ainu communities depended on a complex and interrelated web of foodgathering activities, one of the most important being salmon fishing. In autumn, cherry and dog salmon would swim up the rivers of Ainu territory to spawn, and villagers in the mountain valleys would catch the salmon using spears or bag-nets. ${ }^{59}$ During the Ainu salmon fishing season, relatively small numbers of fish were taken, and these were often caught after they had spawned. By contrast, the Japanese fishing enterprises, which entered the region in growing numbers during the late Tokugawa period, used large nets to catch the fish as they entered the river mouth. The result was a drastic drop in salmon stocks, which caused hardship and even famine in some inland Ainu settlements. Driven by hunger, villagers left the inland districts for the coast, where they often found employment as fishery workers. ${ }^{60}$ The drift of population away from the mountains further undermined the balance of hunting, fishing and crop growing that had characterised the inland Ainu economy.

In other words, the incorporation of Ainu society into an increasingly close economic relationship with Japan encouraged a shift from a relatively diversified, self-sufficient economy to one that concentrated on the areas of particular Ainu 'comparative advantage': hunting and fishing. This led not only to a diminution of farming, but also to the disappearance of other activities for which Japan was more advantageously placed. One of the most important examples was metalworking. When Mamiya Rinzō reached Sakhalin in the early nineteenth century, he found Ainu blacksmiths using techniques quite different from those that existed in Tokugawa Japan. ${ }^{61}$ This type of metalworking, he noted, had existed until recently in other parts of Ainu territory (including the north of modern Hokkaido), but had gradually vanished in the face of Japanese imports of metal goods. Many modern texts on Ainu culture deny that they ever possessed the ability to make metal tools. ${ }^{62}$ The process of declining self-sufficiency in early modern Ainu society is also emphasised by the historian Kaiho Mineo, who focuses particularly on the disappearance of Ainu pottery and on growing Ainu dependence of Japanese-made tools. ${ }^{63}$

59 Hiroshi Watanabe, The Ainu Ecosystem (Seattle and London: University of Washington Press. 1972) p. 31.

60 Uemura Hideaki, Kita no Umi no Köekishatachi: Ainu Minzoku no Shakai Keizaishi (Tokyo: Dōbunkan Shuppan. 1990), pp. 230-32.

61 Mamiya, 'Kita Ezo Zusetsu', pp. 338-42.

62 For example, Hayashi, Ainu no Nōkō Bunka, p. 31; Takakura, Shinpan Ainu Seisakushi, p. 31.

63 Kaiho Mineo, Kinsei no Hokkaidō (Tokyo: Kyōikusha, 1979), pp. 96-97. 


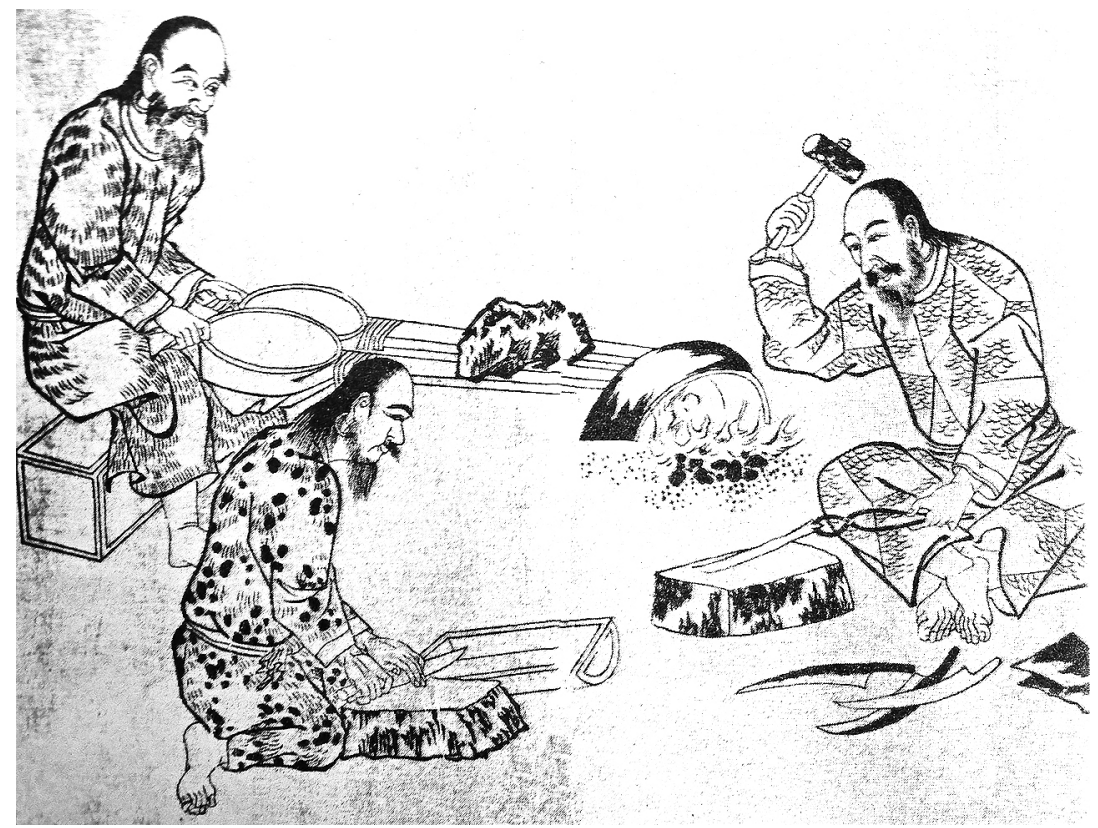

Figure 4.5. Sakhalin Ainu blacksmiths.

Source: Mamiya Rinzō, 'Kita Ezo Zusetsu or a Description of the Island of Northern Yezo by Mamiya Rinsō', trans. John A Harrison, Proceedings of the American Philosophical Society 99, no. 2 (1955). Originally published in 1855.

It seems probable, then, that it was the very process of increasing trade with an evolving and expanding Japanese economy that tended to reconstitute Ainu society as an archetypal 'hunter-gatherer' society. The growth of trade promoted a more sharply defined division of labour between Japan and the Land of the Ainu: a division in which the latter specialised in fishing and hunting while the former specialised in farming and metalworking. Such patterns of change are not unique to the Okhotsk region. In the North American context, for example, Stephen Cornell has documented the way in which the colonial fur trade transformed the life patterns of Native American peoples. Cornell points out that the fur trade did not simply mean that increasing amounts of time were spent in hunting and trapping animals, but also that new techniques for skinning and processing had to be developed or acquired from the European colonists. As the fur trade expanded: 
hunting grew in importance, to the detriment of agriculture. Crucially, it was hunting on an increasingly commercial, instead of subsistence, basis. The purpose of the hunt was no longer simply to secure food, hides and other products for home consumption, but to sustain trade relationships with Europeans. ${ }^{64}$

This commercialisation of life had other lasting effects:

As Indian material goods were replaced by European ones, some traditional crafts fell into disuse. Eventually some were forgotten. Trade items once considered luxuries or conveniences became necessities. At the same time new wants emerged that could be satisfied only by European products. ${ }^{65}$

\section{Imbricated History in an Age of Climate Change}

The story told here, then, highlights the importance of re-examining the historical importance and dynamics of small, decentralised knowledge systems; and the significance of their history has recently been highlighted by twenty-first-century environmental challenges, particularly the challenge of global warming. In recent years, there has been a growing interest in 'Big History', ${ }^{66}$ and a growing acceptance of the view that the macro-history of our planet has entered a new era - the Anthropocene - in which 'humankind has become a global geological force in its own right'. ${ }^{67}$ A core characteristic of Big History, in the words of its pioneer David Christian, is:

its interdisciplinary nature and its search for an underlying unity beneath the various accounts of the past told in different historically oriented disciplines. Big History studies the past across physics, astronomy, geology, biology and human history. ${ }^{68}$

64 Stephen Cornell, The Return of the Native: American Indian Political Resurgence (Oxford: Oxford University Press, 1988), p. 23.

65 Cornell, Return of the Native, p. 22.

66 See, for example, David Christian, Maps of Time: An Introduction to Big History (Berkeley: University of California Press, 2004); Fred Spier, Big History and the Future of Humanity (Oxford: Wiley-Blackwell, 2010); David Christian, Origin Story: A Big History of Everything (Harmondsworth: Penguin Books, 2018).

67 Will Steffen, J Grinevald, P Crutzen and John McNeill, 'The Anthropocene: Conceptual and Historical Perspectives', Philosophical Transactions of the Royal Society A: Mathematical, Physical and Engineering Sciences 369 (2011): pp. 842-67, quotation from p. 843, doi.org/10.1098/rsta.2010.0327. 68 David Christian, 'Preface to the 2011 Edition', in Maps of Time: An Introduction to Big History, rev. ed. (Berkeley: University of California Press, 2011), p. xxiv. 
To achieve this grand synthesis, Big History, as it were, takes a step back from the human past, allowing us to observe human history as just one part of the much bigger processes of becoming that begin from the Big Bang. The result is in some ways a radically new approach to thinking and writing about history. Dipesh Chakrabarty has similarly advocated a fundamental transformation of the timescale of history, creating a view of the past that embraces the vast and slow movement of planetary time. He sees the subject of history not as individuals, nations, ethnic groups, social classes etc., but as the planetary system itself, of which the human race is just one small part. ${ }^{69}$

Historian of Japan Julia Adeney Thomas, whose work is deeply influenced by Chakrabarty's, argues that the study of the diverse historical trajectories of past societies around the world is crucial to enable us to find alternative historical futures that diverge from the endless pursuit of material wealth and power. She emphasises the urgency of developing a different sort of history writing, which might enable us to appreciate how the human body is inseparably embedded in its environment, and which might thus make it possible for us to conceive of a new economic and political order to counter 'neoliberalism's naturalization of infinite economic expansion'. ${ }^{70}$ One important historical experience in this context, she suggests, is the story of Tokugawa Japan, which (according to the accounts of historians like Geoffrey Parker) appears to have weathered the climatic changes of the Little Ice Age with relatively little social disruption. ${ }^{71}$ Thomas argues that, in the search for a different vision of past and future, we may find hope in the resilience of Tokugawa Japan, which 'was fairly isolated from the rest of the world and did not export its human population and did not import food, and managed to live for 250 years in peace..$^{72}$

Here I would like to suggest a somewhat different way of thinking about this profound problem - one that moves not up to the grand scale of geological history, but down to the small scale of decentralised knowledge

69 Dipesh Chakrabarty, 'Anthropocene Time', History and Theory: Studies in the Philosophy of History 51, no. 1 (2018): pp. 5-32.

70 Julia Adeney Thomas, 'History and Biology in the Anthropocene: Problems of Scale, Problems of Value', The American Historical Review 119, no. 5 (2014): pp. 1587-607, quotation from p. 1606, doi.org/10.1093/ahr/119.5.1587.

71 See Geoffrey Parker, The Global Crisis: War, Climate Change and Catastrophe in the Seventeenth Century (New Haven: Yale University Press, 2013), particularly Chapter 16.

72 John McNeill and Julia Adeney Thomas, 'Historians and the Anthropocene' (lecture, Woodrow Wilson Center History and Public Policy Program, 17 November 2017, www.youtube.com/watch? $\mathrm{v}=\mathrm{xhrP} 1 \mathrm{hZuW0M}$ (accessed 17 December 2018)). 
systems and their imbricated history. Viewed from the perspective of the Okhotsk region, the history of Tokugawa Japan does not look much like a story of peace and isolation, but rather like one of northward expansion and of the exploitation both of human and natural resources. The tendency to see Tokugawa Japan as self-contained and non-expansionist is largely a product of a projection of Japan's contemporary national boundaries back onto the past, obscuring the story of the eighteenth- and early nineteenth-century Japanese state's economic encroachments both to the south and to the north. What comes to the fore when we look at the history of the Okhotsk, rather, is a striking picture of the drastic destruction of small-scale knowledge systems as the borders of Japanese state power moved northwards and those of Russian state power moved eastwards from the late eighteenth century onwards. Japan was able to maintain its high population density despite limited trade with other nation-states partly because it was able to exploit the resources of Ezo - particularly the region's rich fish resources, which were converted to fertiliser and used to enrich the soil for Japanese rice agriculture.

The very success and material might of the centralised and globalised knowledge system that took shape from the sixteenth century onward allowed it to subordinate and displace a multitude of small-scale knowledge systems around the world. Although (as we shall see) this did not necessarily mean that the ideas and traditions generated by such systems disappeared altogether, it did profoundly erode their integrity and autonomy. Some of the consequences of this process are now all too apparent as we face the challenge of anthropogenic climate change. It is, of course, a profound irony that the globalised system of modern science and technology, which unleashed the forces that create climate change, also plays an essential role in providing the scientific tools that allow us to track and predict global warming. But the centralised knowledge system that is so effective in calculating aggregate patterns of climate change is notoriously bad at predicting the impacts that these patterns will have on specific local environments and their inhabitants (including their vast diversity of animal and plant inhabitants). The complexity of the way that global trends like climate change play out in specific places demands the kind of intricate local knowledge of geology, weather, living creatures and their interactions in which small-scale knowledge systems like those of the Okhotsk excelled. But much of that knowledge has now been lost or deliberately destroyed; and we have also lost the flexibility and adaptability that was created by the existence of the wide diversity of distinct but interrelated social forms and systems of knowledge and subsistence. 
This is not to suggest, of course, that we can find a solution to contemporary global problems in nostalgia for indigenous pasts, or in attempting to recreate long-vanished social systems. We are now, to varying degrees, all embedded in a centralised global knowledge system, and must find our way out of our present predicaments from within that system. But an attempt to understand the diversity of, and interaction between, the knowledge systems of the past may help us at least to glimpse what Julia Thomas calls 'multiple viable ways of life' - the many possibilities that exist within the human historical experience. ${ }^{73}$ One important part of this discovery of the history of interaction between diverse knowledge systems is an exploration of the way in which small-scale knowledge systems like those of the Okhotsk responded to the overwhelming arrival of a globalised order armed with science, modern weaponry and an unshakable faith in its own civilisational superiority. In fact, despite great inequalities of material and military power, the outcome of the interaction between global and national knowledge systems (on the one hand) and the local systems of colonised small societies (on the other) proved complex. It is true that in some places existing small societies were totally destroyed by the processes of world expansion, and that everywhere their ways of life were changed forever. In some cases, though, the interaction produced more subtle and surprising results. In the three chapters that follow, we shall examine some aspects of this interaction and its historical legacies. 
This text is taken from On the Frontiers of History: Rethinking East Asian Borders, by Tessa Morris-Suzuki, published 2020 by ANU Press, The Australian National University, Canberra, Australia.

doi.org/10.22459/OFH.2020.04 